\title{
PENGARUH LATAR BELAKANG PENDIDIKAN AGAMA DAN SEMANGAT WIRAUSAHA TERHADAP KINERJA BISNIS MAHASISWI MUSLIMAH ENTERPREUNER DI KOTA BANDUNG
}

\author{
Diden Rosenda \\ SMAN 3 Bandung \\ Email: rozenda69@gmail.com
}

\begin{abstract}
Abstrak
Tujuan penelitian ini adalah untuk mengetahui pengaruh latar belakang pendidikan agama, dan semangat wirausaha terhadap kinerja bisnis mahasiswi muslimah enterpreuner di Kota Bandung. Penelitian ini menggunakan jenis penelitian kualitatif dengan pendekatan analisis deskriptif. Data dalam penelitian terdiri data primer dan data sekunder. Metode pengumppulan data menggunakan metode wawancara dan studi pustaka guna. Responden penelitian adalah 45 mahasiswi pebisnis dari berbagai Universitas di Kota Bandung. Responden penelitian menggunakan metode Purposive Sampling. Mahasiswi yang memiliki latar belakang pendidikan agama di pesantren mednapatkan angka tertinggi dalam hubungannya dengan peningkatan kinerja bisnis, Hal tersebut karena di pondok pesantren responden diajakrkan karakter seorang wirausaha yang mandiri, jujur, disiplin, pekerja keras, tidak mudah menyerah dan inovatif. Mahasiswi yang mempunyai semangat beribadah dalam menjalankan bisnisnya memperoleh nilai yang paling tinggi dalam hubungannya dengan kinerja bisnis.
\end{abstract}

Kata Kunci: Pendidikan Agama, Semangat Wirausaha, Kinerja Bisnis, Muslimah Enterpreuner.

\begin{abstract}
The purpose of this study was to determine the effect of religious education background, and entrepreneurial spirit on the business performance of Muslim female entrepreneurs in Bandung. This research uses qualitative research with descriptive analysis approach. The data in the study consisted of primary data and secondary data. Methods of collecting data using interview methods and literature study. The research respondents were 45 business students from various universities in the city of Bandung. Research respondents used the purposive sampling method. Students who have a religious education background in Islamic boarding schools get the highest score in relation to improving business performance, This is because in Islamic boarding schools respondents are taught the character of an entrepreneur who is independent, honest, disciplined, hardworking, not easy to give up and innovative. Students who have the spirit of worship in running their business get the highest score in relation to business performance.
\end{abstract}

Keywords: Religious Education, Entrepreneurial Spirit, Business Performance, Muslim Entrepreneur.

\section{A. PENDAHULUAN}

Kata entrepreneurship berasal dari bahasa Perancis entreprendre dan bahasa Jerman unternehmen. Kedua kata kerja diterjemahkan menjadi "melakukan" Di satu sisi, wirausahawan melakukan upaya yang tidak dilakukan orang lain. Pengusaha sekaligus salah 
satu yang paling menarik dan salah satu hal yang paling sulit dipahami dalam subjek analisis ekonomi (Ayu, 2017).

Konsep kewirausahaan pertama kali dicetuskan pada tahun 1700-an, dan mengacu pada kegiatan yang berkaitan dengan upaya untuk mendirikan industri atau pendirian usaha. Kewirausahaan memiliki arti yang berbeda bagi orang yang berbeda (Zurani, 2020). Dalam praktiknya, Kewirausahaan adalah tentang menciptakan sesuatu yang baru atau menemukan cara baru untuk membuat sesuatu yang sudah ada. Seorang wirausahawan melakukan inovasi atau memperkenalkan hal-hal baru untuk mengubah inovasi menjadi barang ekonomi. Drucker (1985) menyatakan bahwa Kewirausahaan bukanlah ilmu atau seni. Ini adalah praktik. Pengusaha menggeser sumber daya ekonomi dari area yang lebih rendah ke area produktivitas yang lebih tinggi dan hasil yang lebih besar. Dalam ilmu ekonomi, kewirausahaan yang dipadukan dengan tanah, tenaga kerja, sumber daya alam, dan modal dapat menghasilkan keuntungan (Wahyudi \& Kurnasih, 2021). Wirausahawan adalah orang yang memobilisasi sumber daya untuk keuntungan lebih dengan menurunkan biaya. Pengusaha mengembangkan barang atau proses baru yang diminta pasar dan saat ini tidak dipasok. Inovasi diperlukan untuk mengembangkan metode baru dalam proses produksi, menggali sumber bahan baku baru, menemukan segmen pasar baru, dan mengembangkan strategi. Seorang wirausahawan adalah tipe pengambil risiko, pembuat keputusan yang cerdas, mengenali peluang keuntungan potensial, dan mengkonseptualisasikan strategi untuk mengembangkan usaha (Illahiati, 2017).

Kewirausahaan Islam adalah melakukan bisnis dengan inovasi, risiko dan dengan pedoman ketat yang ditetapkan oleh Islam untuk mengatur akumulasi keuntungan dengan melarang ketidakjujuran, keserakahan, eksploitasi, dan monopoli. Nabi Muhammad (SAW) menjelaskan bahwa seseorang yang memperoleh keuntungan dari jalan yang bathil adalah orang berdosa. Pengusaha Muslim diizinkan dan didorong untuk terlibat hanya dalam kegiatan bisnis produktif yang diterima secara moral dan diinginkan secara sosial. Kegiatan yang melibatkan alkohol, narkoba, riba, prostitusi, perjudian, dan perilaku bisnis yang sangat spekulatif dilarang keras (Nur \& Harriyanti, 2019). Pengusaha Muslim harus berbeda dari pengusaha lain dalam motif dan tujuan mereka. Diharapkan jika mereka berhasil mengelola usahanya, mereka juga harus memiliki kinerja yang baik dalam hal keimanan dan ketaqwaan kepada Allah SWT.

Peran agama (Islam) adalah bahwa ia memberlakukan beberapa pembatasan dalam melakukan bisnis bagi umat Islam sambil berperilaku religius. Pembatasan yang dipaksakan pada hakikatnya ingin untuk kepentingan orang atau pihak yang bersangkutan. Secara alami, tidak adanya undang-undang dan batasan tersebut dapat dengan mudah menyebabkan orang atau organisasi berperilaku tidak normal, yang akan menciptakan ekses, penyalahgunaan, dan konflik (Heriyanto, 2017).

Dalam budaya masyarakat modern di Indonesia, pendidikan di tuntut untuk berperan aktif dalam mengatasi ketimpangan gender. Hal tersebut seringkali terabaikan karena beberapa faktor, misalnya: 1) Penafsiran agama secara sempit seringkali membenarkan ketidaksetaraan dan ketidakadilan, diperlukan kemauan secara kultural dan struktural untuk mengubah paradigma pandidikan Islam; 2) Kurangnya pendidikan kesetaraan gender, dan belum dirumuskan dalam pendidikan nasional; 3) Akses, kontrol, dan orientasi gender dalam budaya masyarakat yang masih rendah; dan 4) Kurangnya hak dan kewajiban perempuan dalam melaksanakan kewajibannya secara mandiri melalui pendidikan. Tingkat partisipasi perempuan dalam pendidikan dinilai masih rendah. Memperluas literasi menjadi faktor yang penting guna meningkatkan hal tersebut (Suranto et al. 2018).

Termasuk dalam kajian ekonomi perempuan pebisnis masih dianggap tabu di kalangan masyarakat secara luas, terutama dalam masyarakat mayoritas Muslim di Indonesia. Perempuan dalam persepektif masyarakat, masih dikekang dengan paradigma pekerjaan 
domestik seperti mengurus rumah tangga, menjaga kebersihan lingkungan, mendidikan anak, memaskan, serta keperluan lain (Septiani et al. 2020). Namun dalam budaya masyarakat modern, hal ini sedikit bergeser karena telah banyak perempuan yang menjadi pebisnis, dan mencukupi kehidupannya secara mandiri, dan faktor kunci hal tersebut adalah pendidikan.

Hal tersebut dikuatkan oleh penelitian yang dilakukan oleh Indria Nur (2019), pentingnya Institusi pendidikan Islam untuk ikut berperan dan bergerak dalam mengubah persepsi masyarakat tentang hak-hak perempuan di Papua Barat, termasuk dalam hal ekonomi guna memenuhi kebutuhannya sebagai manusia. Pendidikan berbasis gender diperlukan untuk mempersiapkan kebutuhan hidup yang berbeda dan terbukti lebih efektif dalam menemukan metode pengajaran yang sesuai dengan karakteristik gender. Selain itu, perlu juga merevisi materi pendidikan agama yang umumnya dilaksanakan dengan memahami bias gender profesional. Gerakan inovasi pendidikan agama tentang kesetaraan dan keadilan (equity) antara perempuan dan laki-laki dalam akses ekonomi, sosial budaya, dan politik (Hardilawati et al. 2018).

Selain menjadi destinasi wisata, Kota Bandung juga terkenal dengan inovasinya yang tinggi dan kreatif dalam berbagai bidang bisnis. Hal itu membuat masyarakat Kota Bandung menjadi tempat parta pengusaha bertemu dan membuat forum bisnis, forum tersebut diisi oleh mayoritas anak muda dan masyarakat dari berbagai latar belakang, termasuk perempuan. Hal tersebut dapat terlihat dari banyaknya akun influencer wanita yang menekuni bisnis dalam berbagai bidang, seperti kuliner, fashion, bahkan menjadi konsultan. Bahkan, dalam website HEEPSY yang memuat daftar Top 10 Most Popular Influencer Enterpreneurs di Kota Bandung pada tahun 2021, akun @mira_bila menjadi akun yang masuk dalam deretan tersebut. Bahkan dalam masa pandemi ini, kian banyak lagi webinar yang mengangkat tema 'Woman Leader' dan 'Woman Enterpreuner' sebagai tema utama. Hal ini tentu menandakan bahwa era digital telah merubah sedikit demi sedikit persepsi masyarakat tentang Muslimah Enterpreuner.

Banyak orang yang masih pesimis dan ragu memulai dan mengembangkan usaha dikarenakan persepsi tentang memulai bisnis yang harus memiliki modal yang sangat besar. Di Kota Bandung sendiri, sudah banyak mahasiswi yang telah sukses membangun usaha dan menjadi seorang pebisnis. Sebagai contoh, sebanyak 60 mahasiswa SBM ITB telah melakukan pendampingan usaha terhadap 234 UMKM di Jawa Barat. Pendampingan tersebut mulai dari proses pencarian bahan produk, pengemasan, pemasaran hingga manajemen keuangan usaha.

Pada era teknologi ini, banyak mahasiswi yang menggunakan media sosial sebagai media online marketing terutama Instagram, penelitian yang menguatkan hal tersebut diantaranya adalah hasil penelitian yang dilakukan Sofia Miranda (2017), hasil penelitian tersebut menyimpulkan bahwa Instagram sebagai media online shopping berpengaruh positif dan signifikan terhadap perilaku konsumtif mahasiswi. Hal tersebut menjadi pasar para pebisnis, terutama pebisnis fashion yang dapat dijadikan target pasar produk udahanya.

Hal tersebut dianalisa oleh David Emile Durkheim dengan istilah yang populer disebut dengan "Structural Funcionalism", masyarakat dipandang sebagai sebuah sistem yang bagian-bagiannya saling terikat dan tidak bisa dipahami secara terpisah dari sudut pandang secara keseluruhan. Nilai didefinisikan sebagai jenis kepercayaan, yang terletak secara terpusat dalam sistem kepercayaan masyarakat, tentang bagaimana seseorang seharusnya atau tidak seharusnya berperilaku, atau tentang beberapa hal yang layak atau tidak layak untuk dicapai. Perubahan di bagian mana pun mengarah pada ketidakseimbangan yang mengubah bagian lain dari sistem dan kadang-kadang, sistem secara keseluruhan. Nilainilai membentuk setiap budaya yang dianggap normal oleh orang-orang dari budaya itu. Hal inilah yang menuntut bahwa pendidikan untuk merubah perspektif masyarakat dalam menilai hak-hak dan kewajiban perempuan perlu dilakukan secara struktural dan kultural. Adanya 
diskriminasi dan bentuk-bentuk ketidakadilan gender merupakan pengaruh dari budaya lokal dan penafsiran metode ayat-ayat Al-Qur'an yang kurang terhadap perempuan. Hal ini karena ayat-ayat Al-Qur'an dipahami sebagian dan tidak kontekstual. Diharapkan pula pendidik dan peserta didik (terutama mahasiswa) perlu mengubah paradigma dan pola pikir yang peka terhadap kesetraaan gender, terutama dalam konteks ekonomi.

\section{B. TINJAUAN PUSTAKA}

\section{Pendidikan Agama}

Dalam kehidupan sosial kemanusiaan, pendidikan bukan hanya upaya memberikan pembelajaran proses yang bertujuan untuk membawa laki-laki/perempuan menjadi sosok yang potensi intelektualnya (intellectual oriented) melalui transfer ilmu sangat didorong. Namun, proses tersebut juga mengarah pada upaya pembentukan karakter masyarakat, etika, dan estetika melalui transfer nilai-nilai yang terkandung di dalamnya.

Hal ini senada dengan fungsi dan tujuan pendidikan nasional sebagaimana diatur dalam Undang-Undang Republik Indonesia Nomor 20 Tahun 2003, Pasal 3 tentang Sistem Pendidikan Nasional, yang menyatakan bahwa pendidikan nasional berfungsi untuk mengembangkan keterampilan dan membentuk watak serta peradaban bangsa yang bermartabat dalam rangka mencerdaskan kehidupan bangsa. kehidupan berbangsa, yang bertujuan untuk mengembangkan potensi siswa dalam rangka Menjadi manusia yang beriman dan bertakwa kepada Tuhan Yang Maha Esa, berakhlak mulia, sehat, berilmu, cakap, kreatif, mandiri, dan menjadi warga negara yang demokratis.

Fungsi dan tujuan pendidikan nasional sangat jelas bahwa tujuan utama pendidikan adalah aspek pembentukan karakter manusia, aspek iman, dan moralitas. Pendidikan tidak lepas dari visi pembangunan yang ditujukan untuk terwujudnya masyarakat Indonesia yang damai, demokratis, berkeadilan, berdaya saing, maju, dan sejahtera, dalam NKRI (Negara Kesatuan Republik Indonesia) yang didukung oleh laki-laki/perempuan Indonesia yang sehat, mandiri, beriman, berakhlak mulia, cinta tanah air, sadar hukum, dan berwawasan lingkungan, menguasai ilmu pengetahuan dan teknologi, dan mengembangkan karakter disiplin yang kuat. Dalam konteks kota Bandung, Pendidikan Agam didapatkan dari berbagai sumber, diantaranya adalah: 1) Pondok Pesantren; 2) Kajian Rutin; 3) Halaqoh; 4) Kajian di kampus; dan 5) Kajian secara virtual.

Pesantren sebagai salah satu lembaga pendidikan telah diakui pengaruhnya yang besar dalam perkembangan dunia pendidikan, khususnya di masyarakat Indonesia. Pesantren juga diyakini dapat menjadi alternatif pemecahan berbagai permasalahan pendidikan yang terjadi saat ini. Pesantren merupakan lembaga pendidikan Islam tertua di Indonesia. Menurut para ahli, pondok pesantren dapat disebut "sekolah agama" apabila memenuhi 5 syarat, yaitu: (1) kyai atau ustadz atau ustadz di Jawa, (2) Pondok atau pondok, (3) masjid atau musholla. , (4) santri, dan (5) Kitab Kuning atau kitab kuning atau kitab klasik Islam.

Sebagai sebuah komunitas dan lembaga yang besar jumlahnya dan tersebar luas di berbagai pelosok tanah air, pondok pesantren telah banyak berperan dalam pembentukan mental bangsa Indonesia yang religius. Oleh karena itu, lembaga ini telah melahirkan banyak pemimpin di masa lalu, sekarang, dan juga masa depan. Para lulusan pondok pesantren, termasuk perempuan tak ayal, banyak yang ikut berperan aktif dalam pembangunan bangsa. Tapi, di sisi lain, ada juga anggapan bahwa lulusan pesantren sulit diajak untuk berkembang, terutama dalam membangun perkeonomian. Hal ini dikarenakan sistem pendidikan di pondok pesantren sebagian besar masih tradisional.

\section{Semangat Wirausaha}

Gairah dan semangat dalam berwirausaha menjadi sebuah karakter penting bagi seseorang untuk berproses dan mengembangkan diri dalam berbisnis. Pengusaha ynag 
memiliki gairan dan passion dalam menjalankan bisnis akan merasa nyaman dengan identitasnya sebagai founder perusahaan dan mengangap hal tersebut adalah suatu pencapaian yang layak untuk di banggakan. Gairah wirausaha dapat didefinisikan sebagai kesadarans erta intensitas perasaan positif dalam kegiatan wirausaha. Menurut Caniago \& Hayati (2019), semangat adalah keyakinan yang kuat, dan dorongan yang membuat orang disiplin untuk mencapai visinya. Impian seseorang dapat terwujud jika memiliki semangat dan niat untuk mewujudkannya. Semangat yang kuat untuk berwirausaha akan menciptakan kepekaan yang mengacu pada membaca apa yang mungkin menjadi peluang di luar sana. Seperti yang telah dijelaskan sebelumnya, semangat untuk kegiatan kewirausahaan dalam konteks tertentu dapat memicu perencanaan startup bisnis terkait konteks. Ketika wirausahawan terlibat dalam hal baru, gairah muncul sebagai emosi untuk mempengaruhi visi, misi, dan keputusan dalam perencanaan.

Dalam era teknologi seperti saat ini, teknologi sangat berperan dalam menambah semangat berwirausaha, terutama generasi millenial yang aktif dan 'melek teknologi'. Berdasarkan penelitian yang dilakukan oleh Dina Mardiana \& Daniar Chandra Anggraini (2019), sebagai salah satu bentuk nyata dari revolusi informasi, internet telah menciptakan konvergensi media melalui jaringan digital. Proses penggabungan atau konvergensi akan dapat berjalan dengan baik. Dapat diterima oleh masyarakat luas - termasuk masyarakat akademik- melalui jalur diseminasi yang menyadarkan masyarakat lain bahwa ada perubahan dan perkembangan teknologi. Oleh karena itu, teknologi komputer berbasis internet ditujukan untuk efektivitas, efisiensi, peningkatan kualitas pembelajaran, dan sebagai media pengembangan bisnis.

Selain itu, pengusaha juga harus memiliki kemampuan untuk mengidentifikasi peluang yang tidak terlihat oleh orang lain, atau dapat juga dikatakan bahwa pengusaha harus memiliki kepekaan terhadap sekecil apapun hal yang dapat dikembangkan dalam bisnis. Pengusaha yang tidak memiliki semangat dan kepekaan tidak akan dapat mengidentifikasi peluang karena tidak akan memiliki pasar yang baik.

Pengusaha muslimah memulai dan mengelola bisnisnya mengikuti pedoman Islam. Pengusaha Muslimah dengan hati-hati menghindari penimbunan yang tidak diinginkan, perlakuan buruk terhadap karyawan dan transaksi yang tidak adil dengan pelanggan. Mencari keuntungan bukan satu-satunya tujuan kewirausahaan Islam. Sebaliknya, pendapatan dari kepuasan yang terbagi, kesejahteraan sosial, dan kekuatan perlindungan kepentingan nasional seperti kewirausahaan. Untuk mengatasi tantangan pesaing dan mengidentifikasi peluang bisnis dari lingkungan yang mudah berubah di era disrupsi, dengan demikian wirausahawan harus berpikir secara strategis. Sensitivitas peluang membaca yang menciptakan keunggulan global melalui budaya dan agama adalah modal yang baik bagi setiap pengusaha.

\section{METODE}

Fokus dan Tujuan penelitian adalah untuk mengetahui pengaruh latar belakang Pendidikan Agama dan Semangat Wirausaha terhadap persepsi masyarakat tentang mahasiswi yang berprofesi sebagai Muslimah Enterpreuner. Penelitian ini menggunakan jenis penelitian kualitatif dengan pendekatan analisis deskriptif. Data dalam penelitian terdiri data primer dan data sekunder. Metode pengunpulan data menggunakan metode wawancara mendalam guna memperoleh data diri dan informasi yang diperlukan dalam penelitian, dan metode kedua yang digunakan yaitu studi pustaka guna memastikan dan menganalisis data hasil dari wawancara. Responden penelitian adalah 45 mahasiswi pebisnis dari berbagai Universitas di Kota Bandung. Responden penelitian menggunakan metode Purposive Sampling. Kriteria pemilihan responden dalam penelitian ini adalah sebagai berikut: 1) Memiliki latar belakang pendidikan agama; 2) Memulai bisnis saat kuliah; 3) Masih berstatus Mahasiswi; dan 4) Berdomisili di Kota Bandung. 


\section{HASIL DAN PEMBAHASAN}

1. Deskripsi Responden Penelitian

Responden penelitian adalah muslimah pebisnis yang masih berstatus sebagai mahasiswa, yang berjumlah 45 orang. Data responden dalam penelitian ini disajikan dalam tabel berikut ini:

Tabel 1. Deskripsi responden penelitian

\begin{tabular}{|c|c|c|}
\hline Usia & Jumlah $(n=45)$ & Persentase $(\%)$ \\
\hline 18-19 tahun & 27 & 60 \\
\hline 20-21 tahun & 5 & 11,12 \\
\hline 22-23 tahun & 8 & 17,78 \\
\hline Pendidikan Agama & Jumlah $(n=45)$ & Persentase (\%) \\
\hline Lulusan Pesantren & 16 & 35,56 \\
\hline Hanya di Perguruan Tinggi & 11 & 24,44 \\
\hline Halaqah & 1 & 2,23 \\
\hline Pengajian Virtual & 9 & 20 \\
\hline Pengajian di Masjid & 3 & 6,67 \\
\hline Sektor Bisnis & Jumlah $(n=45)$ & Persentase (\%) \\
\hline Kuliner & 7 & 15,56 \\
\hline Fashion & 16 & 35,56 \\
\hline Design & 9 & 20 \\
\hline Handicraft & 10 & 22,23 \\
\hline Lainnya & 3 & 6,67 \\
\hline Motivasi/Semangat Bisnis & Jumlah $(n=45)$ & Persentase (\%) \\
\hline Ibadah & 12 & 26,67 \\
\hline $\begin{array}{c}\text { Meningkatkan Kesejahteraan } \\
\text { Keluarga }\end{array}$ & 26 & 57,78 \\
\hline Membuat Lapangan Kerja & 2 & 4,45 \\
\hline Ambisi Pribadi & 5 & 11,12 \\
\hline
\end{tabular}

Sumber: Data diolah

Berdasarkan data di atas, dapat diketahui bahwa mayoritas responden berusia antara 18-19 tahun (60\%), hal ini berarti rata-rata responden masih berada pada fase awal perkuliahan. Dari latar belakang pendidikan, sebagian besar responden $(35,56 \%)$ justru lulusan pesantren, dimana pendidikan agama yang ditanamkan menjadi bekal dan pegangan responden dalam memulai karir usaha. Pendidikan pesantren terbukti mencetak generasi yang mandiri dan dapat memberikan kontribusi bagi perkembangan ekonomi Indonesia. Sektor bisnis responden di dominasi oleh bisnis yang berkembang di bidang Fashion $(35,56 \%)$, bidang ini menjadi populer setelah perkembangan era teknologi sangat pesat, sebagian responden mengaku bahwa mayoritas dari mereka telah memasarkan produk bisnisnya secara online di berbagai platfotm dan media sosial. Sementara itu, motivasi bisnis dari sebagian besar responden $(57,78 \%)$ adalah meningkatkan keejahteraan keluarga, bahkan sebagian dari responden mengaku sudah memiliki beberapa karyawan yang bekerja dalam tim, seperti admin media sosial, dan pengelola keuangan.

\section{Pengaruh Pendidikan Agama terhadap Kinerja Bisnis}

Selanjutnya, responden berdasarkan latar belakang pendidikan agamanya diuji dengan pertanyaan dan pengaruh pendidikan agam terhadap kinerja usaha. Hasil dari aspek ini disajikan dalam tabel berikut ini: 


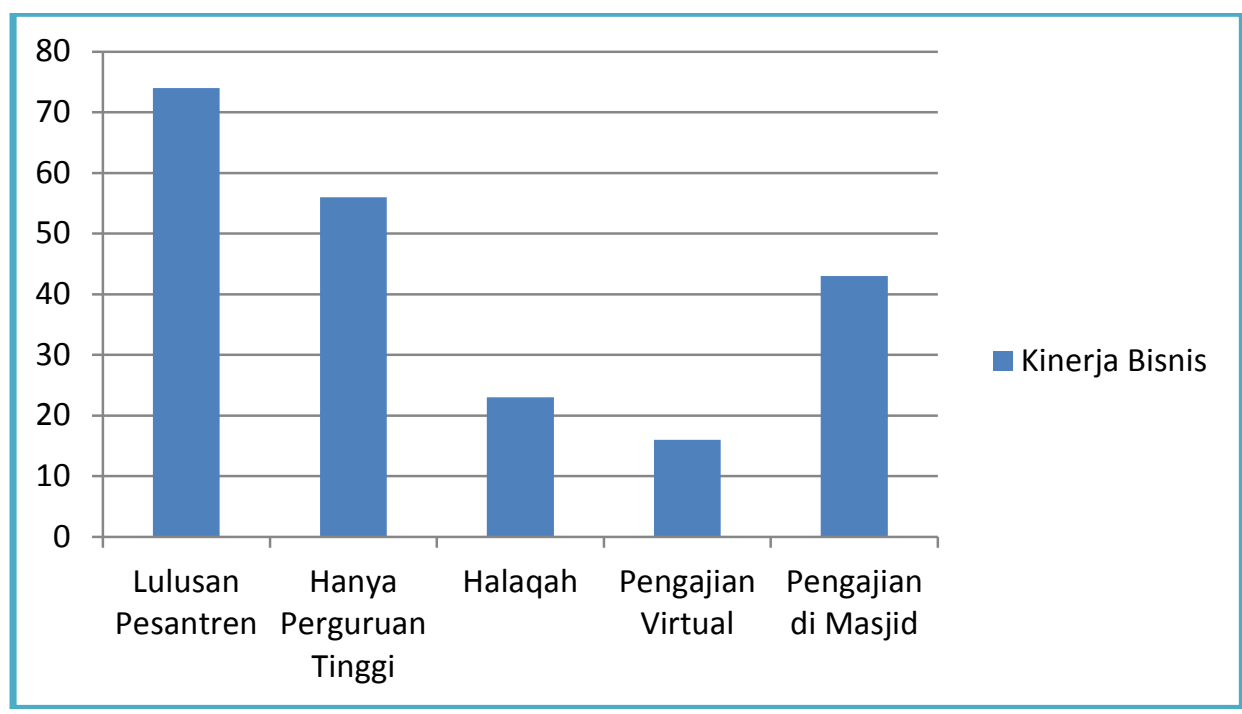

Gambar 1. Pengaruh Pendidikan Agama Terhadap Kinerja Bisnis Sumber: Data Diolah

Berdasarkan hasil penelitian diketahui bahwa responden yang mendapatkan pendidikan agama di pesantren dan perguruan tinggi cenderung lebih tinggi dalam peningkatan kinerja bisnis (74\%), sedangkan yang mendapat pendidikan agama dari halaqah dan pengajian virtual mendapat skor terendah dala peningkatan bisnis, lebih sedikit dari pada responden yang mendapatkan pendidikan agama dari pengajian di Masjid.

Bagi seorang Muslim, menjalankan bisnis adalah ibadah yang harus diawali dengan niat yang suci, cara yang benar, tujuan dan hasil yang benar. Niat yang benar dapat memperoleh jaminan keberhasilan dari Allah SWT. Islam memberikan perhatian yang besar karena merupakan penggerak ruh tubuh kita. Seseorang hanya akan diberi pahala ketika seseorang berniat untuk melakukan aktivitas karena Allah. Imam Ibnu Hajar Al-'Asqalani pernah mengatakan bahwa "Sesungguhnya niat itu kembali pada keikhlasan, dan keikhlasan tidak ada sekutu bagi-Nya". Hal tersebut ditanamkan secara kuat kepada santri pesantren, sehingga motivasinya dalam berbisnis jauh lebih besar.

Hal ini diperkuat oleh hasil penelitian terdahulu yang dilaklukan oleh Miles David (2013), karakteristik wirausaha dikaitkan dengan kinerja mereka untuk mencapai keberhasilan atau kegagalan usahanya, yang diukur dengan melihat kelangsungan hidup atau pertumbuhan bisnis yang dapat dinilai dari niat awal seorang pengusaha. Sebuah bisnis yang sukses membutuhkan pendidikan yang relevan, pengetahuan dan keterampilan yang tepat, dan komitmen untuk memilih tindakan proaktif daripada reaktif. Ini termasuk pengalaman, ketekunan, ketekunan, kepercayaan diri, yang juga dianggap sebagai karakteristik penting untuk keberhasilan pengembangan bisnis apapun. Selain itu, penelitian ini melihat karakteristik wirausahawan Muslim dari perspektif Islam berdasarkan niat mereka untuk melakukan aktivitas wirausaha. Karakteristik tersebut meliputi kecerdasan, kejujuran, dapat dipercaya, kemampuan berkomunikasi dengan baik, serta konsistensi dan keberanian.

Selama satu dekade terakhir, partisipasi perempuan sebagai wirausaha meningkat cukup tajam. Jumlah pengusaha wanita di seluruh dunia telah berkembang dalam beberapa tahun terakhir. Lebih banyak peneliti telah lebih memperhatikan kewirausahaan perempuan. Peran perempuan sebagai pengusaha menjadi lebih signifikan baik di negara maju maupun negara berkembang. Karakternya yang unik dan khas membuat banyak wanita lebih memilih untuk membuka usaha. Peningkatan jumlah wirausahawan wanita disebabkan oleh motivasi yang kuat untuk maju dan tingkat pendidikan yang lebih tinggi. Gupta \& Mirchandani (2018) menemukan bahwa dorongan dan ketertarikan merupakan motivasi dan komitmen seorang wanita untuk menjadi seorang wirausaha. Dalam menjalankan usahanya, para pelaku bisnis khususnya muslimah harus waspada dan waspada untuk ikut terlibat dalam melakukan 
praktik bisnis yang tidak islami. Kewaspadaan kewirausahaan mengacu pada rasa memperhatikan apa yang mungkin untuk mengidentifikasi peluang. Hal ini penting karena membaca peluang bisnis merupakan faktor penting bagi kesuksesan bisnis. Karakter ini banyak ditanamkan dikalangan masyarakat pondok pesantren, atau dikenal sebagai santri.

Di sisi lain, seorang pengusaha sukses biasanya dikaitkan dengan karakteristik tertentu sebagai aset untuk sukses. Hisrich \& Brush (1984) telah mendefinisikan karakteristik disiplin, keinginan untuk berhasil, berorientasi pada tindakan, berorientasi pada tujuan dan memiliki semangat yang besar sebagai karakter seorang enterpreuner. Secara umum sifatsifat yang harus dimiliki wirausahawan Muslim antara lain kejujuran, kebenaran, keadilan, cinta kepada Allah sebagai prioritas, rendah hati, menghindari perilaku curang, kedermawanan, dan motivasi untuk membantu orang lain. Hukum dan aturan Islam mengikat pengusaha Muslim selama pelaksanaan kegiatan kewirausahaan, sehingga mereka harus memiliki kemampuan untuk menjalankan bisnis dengan niat dan tindakan yang baik, transparan dan adil dan menghindari skenario terlarang.

Niat berwirausaha dari perspektif Islam adalah langkah awal dalam melakukan sesuatu dan karena itu berkontribusi pada karakteristik wirausaha. Secara rinci, fathonah menunjukkan karakter wirausaha yang cerdas terkait dengan bagaimana wirausahawan berusaha untuk terus belajar dan memahami konsep wirausaha dan kemudian dapat meningkatkan kompetensinya. Selain itu, karakter Siddiq dan Amanah harus dimiliki oleh setiap wirausahawan, dimana segala niat berasal dari hati sehingga seseorang dapat ditentukan sebagai amanah atau tidak, memiliki integritas atau tidak, jujur atau tidak, yang semuanya bergantung pada niat. Selanjutnya, karakter tabligh menunjukkan bahwa seorang wirausahawan harus mampu menyampaikan informasi dan berkomunikasi dengan orang lain. Kemudian, istiqomah mengusulkan agar semua upaya harus konsisten dengan niat sejak awal. Dengan demikian, wirausahawan Muslim dengan semangat tersebut telah mempengaruhi keberhasilan usahanya, salah satunya adalah wirausahawan muslim yang sukses.

\section{Pentingnya Semangat Wirausaha terhadap Kinerja Bisnis}

Kewirausahaan dari sudut pandang Islam adalah aspek kehidupan yang termasuk dalam muamalah, yang mencakup masalah-masalah yang berkaitan dengan hubungan horizontal antar manusia dan akan dipertanggungjawabkan di akhirat. Jiwa kewirausahaan yang terdapat dalam Al-Qur'an Surat Hud: 61, dan Al-Mulk: 15 menunjukkan bahwa manusia diperintahkan untuk memakmurkan bumi dan membawanya ke arah yang lebih baik, selain itu juga diperintahkan untuk mencari keberuntungan. Jiwa wirausaha yang terdapat dalam Al-Qur'an digambarkan sebagai berikut:

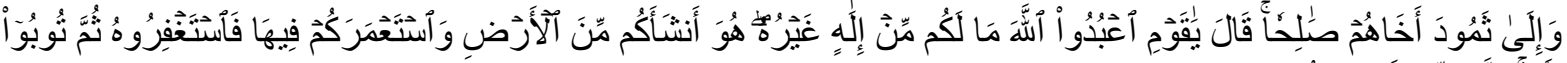

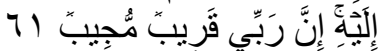

61. Dan kepada Tsamud (Kami utus) saudara mereka Shaleh. Shaleh berkata: "Hai kaumku, sembahlah Allah, sekali-kali tidak ada bagimu Tuhan selain Dia. Dia telah menciptakan kamu dari bumi (tanah) dan menjadikan kamu pemakmurnya, karena itu mohonlah ampunan-Nya, kemudian bertobatlah kepada-Nya, Sesungguhnya Tuhanku amat dekat (rahmat-Nya) lagi memperkenankan (doa hamba-Nya)" (Q.S Hud: 61).

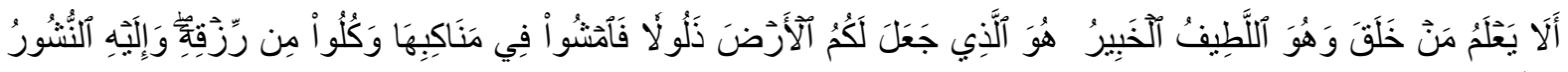


5. "Dialah Yang menjadikan bumi itu mudah bagi kamu, maka berjalanlah di segala penjurunya dan makanlah sebahagian dari rezeki-Nya. Dan hanya kepada-Nya-lah kamu (kembali setelah) dibangkitkan" (Q.S. Mulk).

Hasil penelitian tentang semangat wirausaha dan pengaruhnya terhadap kinerja bisnis responden disajikan dalam gambar berikut ini:

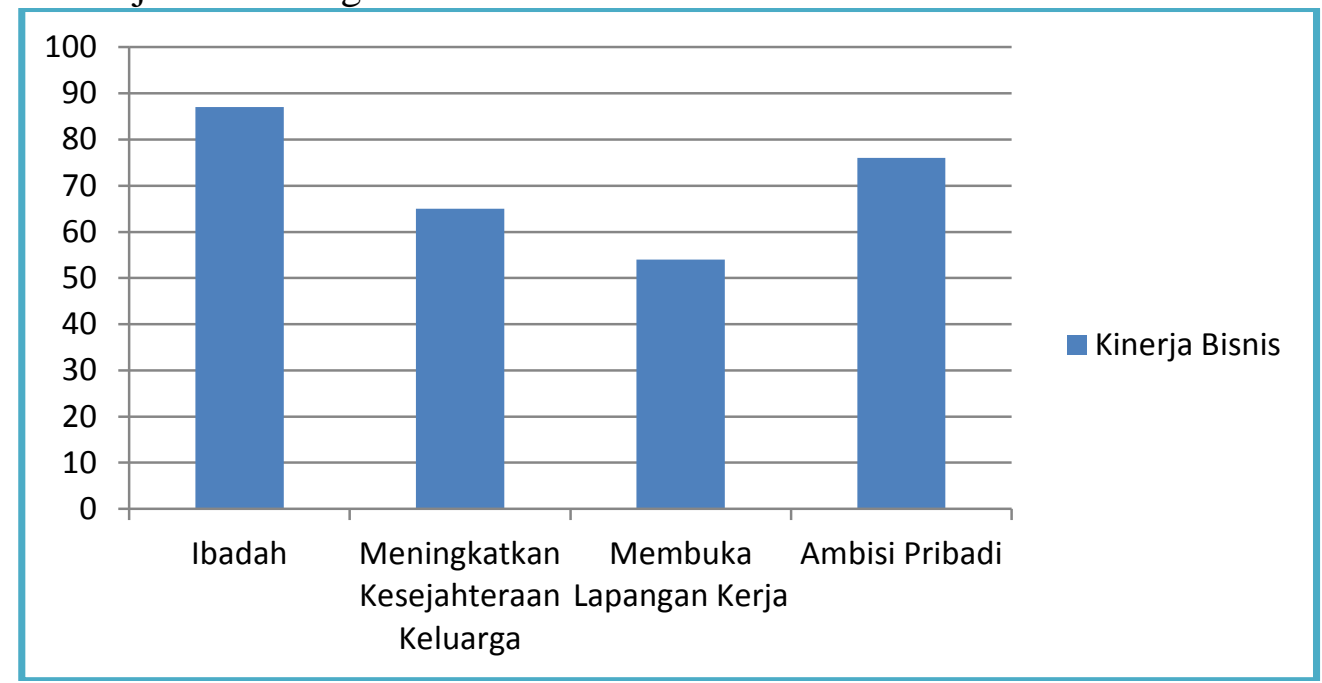

Gambar 2. Pengaruh Semangat Wirausaha Terhadap Kinerja Bisnis

Sumber: Data Diolah

Berdasarkan survei, 36\% responden memiliki semangat berwirausaha untuk berubadah mendapatkan ridho Allah SWT, sedangkan $30 \%$ responden memiliki niat meningkatkan kesejahteraan keluarga. Selain itu, 18\% memiliki niat kewirausahaan untuk mencapai ambisi pribadi, seperti status sosial. Kemudian, sisanya, 16\%, memiliki semangat berwirausaha untuk membuka lapangan kerja.

Selain itu, semangat apapun harus disertai dengan keikhlasan, namun keikhlasan saja tidak cukup untuk menjamin amalan kita diterima oleh Allah SWT jika tidak sesuai dengan syariat Islam yang diatur dalam Al-Qur'an dan Hadits. Selain itu, penelitian ini menyarankan bahwa niat berwirausaha adalah bentuk ibadah kepada Tuhan.

Tahap awal untuk mengarahkan dan menciptakan bisnis adalah passion dari dalam diri. Gairah adalah kecenderungan kuat terhadap suatu aktivitas di mana seseorang merasa seperti, merasa penting, dan ingin menginvestasikan waktu dan energi secara signifikan. Peningkatan penelitian menunjukkan bahwa gairah adalah aspek penting utama dari kewirausahaan, dan memiliki peran penting dalam penciptaan bisnis baik proses maupun hasil Semangat berwirausaha mencerminkan ciri utama yang dimiliki seorang wirausaha, yang merupakan hasil dari perilaku wirausaha. Dimensi semangat kewirausahaan meliputi perasaan positif yang intens dan sentralitas identitas. Semangat ini akan membentuk optimisme wirausaha terkait penilaian wirausahawan dan pengambilan keputusan tentang usaha baru mereka. Meskipun kebiasaan berwirausaha sangat penting untuk penciptaan dan pertumbuhan bisnis, banyak pertanyaan menarik mulai terkuak tentang hasrat berwirausaha, bagaimana dan sejauh mana hasrat berwirausaha dan sensitifitas melihat peluang dalam berwirausaha dapat berkembang dan memengaruhi orientasi kewirausahaan di masyarakat. Kemampuan individu untuk mengidentifikasi peluang dalam bisnis juga merupakan kunci penting. Bagaimana wirausahawan memiliki kemampuan untuk mencari informasi baru, mengasosiasikan setiap informasi dan mengevaluasi informasi baru. Pengusaha muslimah memutuskan untuk terjun ke dunia wirausaha karena memiliki passion tertentu. Mengetahui apa passion yang mereka miliki dalam menjalankan kewirausahaan akan memaksa para wirausahawan untuk mendapatkan informasi terkait bisnis tersebut. Informasi 
Pengusaha muslimah yang berkecimpung dalam berbisnis merupakan salah satu wujud ibadah untuk menggambarkan orang yang taat dan tunduk kepada Allah SWT serta mendapatkan ridho-Nya. Sebagaimana dinyatakan dalam Al-Qur'an ayat Adz-Dhariyat, 51:56, "Aku tidak menciptakan jin dan manusia kecuali untuk beribadah kepada-Ku". Studi saat ini juga menemukan bahwa semangat berwirausaha dalam Islam memberikan beberapa prinsip dasar bagi pebisnis Muslim untuk melakukan bisnis sesuai dengan hukum Islam. Pengusaha Muslim memegang aturan, antara lain tidak merugikan orang lain, aturan jual beli berdasarkan hukum Islam, dan menjalin hubungan sosial yang baik.

Islam menekankan pentingnya semangat dan niat yang mendasari hal tersebut dalam setiap langkah kehidupan seseorang. Seseorang perlu melakukan sesuatu hanya dengan niat untuk menyadari bahwa Allah SWT memantau semua aktivitas yang dilakukan. Dengan demikian, seorang Muslim harus mensyukuri dan melakukan ketentuan di jalan yang benar, serta menyadari bahwa apa yang didapat harus dipertanggungjawabkan kepada Allah SWT. Bahkan, ketulusan juga dapat mengurangi manipulasi atau eksploitasi orang lain untuk alasan pribadi.

Selanjutnya, teori perilaku terencana (TPB) menyoroti niat sebagai faktor utama yang memotivasi perilaku manusia, ditentukan oleh tiga elemen kunci: sikap terhadap perilaku, norma subjektif, dan kontrol perilaku yang dirasakan. Oleh karena itu, pemahaman tentang niat seseorang untuk berwirausaha dapat mencerminkan kecenderungan orang untuk mendirikan bisnis secara nyata. Agama merupakan salah satu pengaruh yang paling universal dan signifikan terhadap sikap, nilai dan perilaku baik pada tingkat individu maupun masyarakat.

Semangat berwirausaha dalam perspektif Islam bertujuan untuk mengabdikan setiap tindakan untuk ibadah kepada Tuhan. Penelitian ini menempatkan ibadah sebagai aktivitas umat Islam dalam menjalankan ajaran agama, yang meliputi aktivitas spiritual, sosial dan ekonomi. Spiritual mengacu pada kegiatan yang mencakup hubungan manusia dengan Tuhan untuk mendapatkan pahala melalui ibadah, yang harus dilakukan oleh umat Islam sesuai dengan perintah dan ajaran-Nya. Kegiatan sosial, yaitu hubungan antar manusia, mengacu pada yang Allah berfirman dalam Al-Qur'an Al-Hujurat 49:10, di mana "Orang-orang yang beriman itu bersaudara, maka berdamailah antara saudara-saudaramu, dan tetaplah bertakwa kepada Allah, agar kamu memperoleh kasih sayang".

Lebih jauh, konsep kewirausahaan dari perspektif Islam mungkin telah mencakup peran penting baik dari segi hukum, masalah sosial atau ekonomi. Dari segi agama, berwirausaha merupakan kegiatan yang sangat dianjurkan untuk meningkatkan kesejahteraan umat. Di sisi sosial, kewirausahaan dapat berdampak pada kondisi sosial dengan menciptakan lapangan kerja dan mengurangi pengangguran. Di sisi ekonomi, kewirausahaan dapat berdampak pada pendapatan masyarakat dan pertumbuhan ekonomi suatu negara. Secara khusus, niat berwirausaha ditafsirkan sebagai langkah pertama untuk membangun bisnis jangka panjang. Niat kewirausahaan dapat mencerminkan komitmen seseorang untuk memulai bisnis baru dan merupakan isu sentral untuk dipertimbangkan dalam memahami proses kewirausahaan dalam mendirikan bisnis baru. Singkatnya, setiap kegiatan wirausaha harus dimulai dari niat wirausahawan untuk menjalankan bisnis dan kemudian mencapai kesuksesan.

\section{E. KESIMPULAN}

Berdasarkann hasil analisis dan pembahasan, dapat disimpulkan bahwa mahasiswi yang memiliki latar belakang pendidikan agama di pesantren mednapatkan angka tertinggi dalam hubungannya dengan peningkatan kinerja bisnis, hal tersebut karena di pondok pesantren responden diajakrkan karakter seorang wirausaha yang mandiri, jujur, disiplin, pekerja keras, tidak mudah menyerah dan inovatif. Mahasiswi yang mempunyai semangat 
beribadah dalam menjalankan bisnisnya memperoleh nilai yang paling tinggi dalam hubungannya dengan kinerja bisnis. Hal ini dikarenakan pemahaman tentang niat seseorang untuk berwirausaha dapat mencerminkan kecenderungan orang untuk mendirikan bisnis secara nyata. Agama merupakan salah satu pengaruh yang paling universal dan signifikan terhadap sikap, nilai dan perilaku baik pada tingkat individu maupun masyarakat.

\section{DAFTAR PUSTAKA}

Ayu, R. K. (2017). Perempuan Pebisnis Startup di Indonesia dalam Perspektif Cybertopia. Jurnal Studi Komunikasi, 1(2), 116-130.

Caniago, I., \& Hayati, K. (2019). Kewirausahaan Teknologi Digital: Potensi Pemberdayaan Pebisnis Milenial.

Gupta, N., \& Mirchandani, A. (2018). Investigating entrepreneurial success factors of women-owned SMEs in UAE. Management Decision

Hardilawati, L. W., Hinggo, H. T., Zaki, H., \& Sinaga, S. M. (2018). Pelatihan Peningkatan Semangat Wirausaha Pada Guru SMA Di Kota Pekanbaru. Jurnal Pengabdian UntukMu NegeRI, 2(1), 50-55.

Hariyanto, R. (2017). Menumbuhkan Semangat Wirausaha Menuju Kemandirian Ekonomi Umat Berbasis Pesantren (Studi Kasus di PP Darul Ulum Banyuanyar Pamekasan). NUANSA: Jurnal Penelitian Ilmu Sosial dan Keagamaan Islam, 14(1), 185-212.

Hisrich, R., \& Brush, C. (1984). The woman entrepreneur: Management skills and business problems. University of Illinois at Urbana-Champaign's Academy for Entrepreneurial Leadership Historical Research Reference in Entrepreneurship.

Illahiati, N. K. (2017). Diskursus Identitas Perempuan Dalam Majalah Perempuan Muslim Indonesia. Bahasa dan Seni: Jurnal Bahasa, Sastra, Seni, dan Pengajarannya, 45(1), 86-98.

Mardiana, D., \& Anggraini, D. C. (2019). The effectiveness of utilising web-learning media towards Islamic education learning (PAI) outcome in the era of industrial revolution 4.0. International Journal of Innovation, Creativity and Change, 8(1), 80-96.

Miles, D. (1995). Optimal regulation of deposit taking financial intermediaries. European Economic Review, 39(7), 1365-1384.

Nur, F. A., \& Hariyanti, N. (2019). Beauty Vlogger: Representasi Perempuan di Era Disrupsi. ETTISAL: Journal of Communication, 4(2), 213-220.

Septiani, E., Santoso, B., Mulyadi, M., \& Muhdin, M. (2020). Peningkatan Semangat Wirausaha Pasca Bencana Gempa Lombok Di Kawasan Wisata Gili Meno. Abdi Insani, 7(3), 242-246.

Suranto, S., Setiawan, E., \& Sujalwo, S. (2018). Menumbuhkan Semangat Wirausaha Mahasiswa Berbasis Potensi. IENACO (Industrial Engineering National Conference) 62018.

Wahyudi, D., \& Kurniasih, N. (2021). Narasi Perempuan dan Literasi Digital di Era Revolusi Industri 4.0. SETARA: Jurnal Studi Gender dan Anak, 3(1), 1-19.

Yadav, V., \& Unni, J. (2016). Women entrepreneurship: research review and future directions. Journal of Global Entrepreneurship Research, 6(1), 1-18.

Zurani, I. (2020). Dominasi Perempuan Pebisnis dalam Rumah Tangga. WACANA: Jurnal Ilmiah Ilmu Komunikasi, 19(1), 72-81. 